$\overline{\text { Original }}$

\title{
Disinfection Effect of Hydrotalcite Compounds Containing Antimicrobial Metals Against Microorganisms in Water
}

\author{
SYUNJI SUNAYAMA ${ }^{1 *}$, TOSHIO SATO ${ }^{1}$, ARIUMI KAWAMOTO ${ }^{2}$, \\ AKIRA OHKUBO ${ }^{2}$, AND TAKASHI SUZUKI ${ }^{3}$ \\ 1 Faculty of Life and Environmental Science, Shimane University, Nishikawatsu 1060, Matsue, \\ Shimane 690-8504, ${ }^{2}$ Tomita Pharmaceutical Co. Ltd., Maruyama 85-1, Akinokami, \\ Seto, Naruto, Tokushima 771-0360, and ${ }^{3}$ Faculty of Engineering, Yamanashi \\ University, Takeda 4-3-11, Kofu, Yamanashi 400-8511, Japan
}

Received 15 November 2001/Accepted 17 December 2001

\begin{abstract}
Hydrotalcites containing copper (Cu-HT) were synthesized using $\mathrm{MgCl}_{2}, \mathrm{AlCl}_{3}$ and $\mathrm{CuCl}_{2}$, and hydrotalcites containing zinc $(\mathrm{Zn}-\mathrm{HT})$ were synthesized using $\mathrm{MgCl}_{2}, \mathrm{AlCl}_{3}$ and $\mathrm{ZnCl}_{2}$. Their disinfection activities against Escherichia coli, Staphylococcus aureus and $E$. coli phage $Q \beta$ (phage $Q \beta$ ) were investigated by the shake-flask method. Cu-HT possessed strong disinfection activities against $E$. coli and phage $Q \beta$, whereas $\mathrm{Zn}-\mathrm{HT}$ showed bactericidal activity against $E$. coli, $S$. aureus and phage $Q \beta$. Copper elution from $\mathrm{Cu}-\mathrm{HT}$ was undetectable during the disinfection test. The disinfection activity of $\mathrm{Cu}-\mathrm{HT}$ was due to the presence of copper. The $\mathrm{pH}$ of $\mathrm{Cu}-\mathrm{HT}$ suspensions was $\mathrm{pH} 9.3$ as a result of the hydration reaction at the surfaces of the Cu-HT particles. The remarkable disinfection activity of $\mathrm{Cu}-\mathrm{HT}$ against phage $Q \beta$ seemed to be based on the cooperative action of copper in Cu-HT and the direct contact of phage $Q \beta$ cells to the hydroxyl layers on the surfaces of the Cu-HT particles. We propose that $\mathrm{Cu}-\mathrm{HT}$ can be used as an alternative disinfectant to chlorine in a water purification system.
\end{abstract}

Key words : Copper-containing hydrotalcite compound/Zinc-containing hydrotalcite compound/ Disinfection effect/Inactivation effect/ $\mathrm{F}^{+} \mathrm{RNA}$ phage $Q \beta$.

\section{INTRODUCTION}

Bactericidal treatment is very important to obtain water that is high safe to use, and chlorination has been mainly used for the disinfection of tap water and sewage. However, with chlorination carcinogenic materials such as the trihalomethanes (THMs), 3-chloro4, 5-dihydroxy-2-furanone (MX) and total organic halogen (TOX) are produced from the variety of organic impurities in water. Moreover, chlorine resistant pathogenic microorganisms such as viruses and protozoa have been found (Hirata and Hashimoto,1997; Taguchi and Yano,1988). These microorganisms are opportunistic pathogens which pose high risks to those with low resistance such as the elderly and the very young.

*Corresponding author. Tel: +81-852-32-6597, Fax : +81-852-32-6589.
Recently, we have developed a new, safe and simple method to inactivate of the viruses and the protozoa. This disinfection method involved inorganic ionexchangers, which held an antimicrobial metal by the ion-exchange method (Sato et al., 2000; Sunayama et al., 1999), and the antimicrobial metal was introduced into the inorganic ion-exchanger structure by changing the composition. Hydrotalcites ( $\left\{\left[\mathrm{M}^{2+} 1-x \mathrm{M}^{3+} \mathrm{X}\right.\right.$ $\left.(\mathrm{OH})_{2}\right] \mathrm{A}^{\mathrm{n}-\mathrm{x}} / \mathrm{n} \cdot \mathrm{mH}_{2} \mathrm{O}$; $\left.\mathrm{HTLC}\right)$ are inorganic compounds with a stratified structure. The structure of the interlayer consists of divalent, trivalent metals and an anion such as $\mathrm{M}^{2+}, \mathrm{M}^{3+}$ and $\mathrm{A}^{n-}$, respectively, and it is possible to introduce into the structure copper or zinc as a divalent antimicrobial.

In this paper, we synthesized HTLC containing copper $(\mathrm{Cu}-\mathrm{HT})$ and zinc $(\mathrm{Zn}-\mathrm{HT})$, and investigated their possible application as a new disinfectant in the water purification system. 


\section{MATERIALS AND METHODS}

\section{Syntheses of Cu-HT and Zn-HT}

Cu-HT was synthesized as follows: $1000 \mathrm{ml}$ of an aqueous salt solution (containing $4.5 \mathrm{M} \mathrm{CuCl}_{2}, 0.5 \mathrm{M}$ $\mathrm{MgCl}_{2}$ and $1.0 \mathrm{M} \mathrm{AlCl}_{3}$ ) and $1000 \mathrm{ml}$ of sodium hydroxide solution $(6.25 \mathrm{M})$ were combined, and the $\mathrm{pH}$ of the solution was adjusted to 11 with a sodium carbonate solution. The reaction mixture was adjusted to about $\mathrm{pH} 12$ by controlling the dropping speeds of the aqueous solutions. The resultant mixture was incubated at $60^{\circ} \mathrm{C}$ for $2 \mathrm{~h}$ while being stirred. Then, precipitates were collected by suction filtration, washed five times with distilled water, and dried at $80^{\circ} \mathrm{C}$.

$\mathrm{Zn}$-HT was synthesized as follows: $1000 \mathrm{ml}$ of an aqueous solution (containing $1.5 \mathrm{M} \mathrm{ZnCl}_{2}, 1.5 \mathrm{M}$ $\mathrm{MgCl}_{2}$ and $\left.1.0 \mathrm{M} \mathrm{AlCl}_{3}\right)$ and $1000 \mathrm{ml}$ of sodium hydroxide solution $(6.25 \mathrm{M})$ were combined, and the $\mathrm{pH}$ of the solution was adjusted to 8 with a sodium carbonate solution. The reaction mixture was adjusted to about $\mathrm{pH} 8$ by controlling the dropping speeds of the aqueous solutions. The resultant mixture was incubated at $60^{\circ} \mathrm{C}$ for $2 \mathrm{~h}$ with stirring. Then precipitates were collected by suction filtration, washed five times with distilled water, and dried at $80^{\circ} \mathrm{C}$.

HT500PF was one of the commercial forms of HTLC intercalating carbonate anion without copper or zinc. HT500PF was used as a control material for the disinfection tests. The chemical formulas, the surface areas and the amounts of metals for $\mathrm{Cu}-\mathrm{HT}, \mathrm{Zn}-\mathrm{HT}$ and HT500PF are shown in Table 1.

\section{Preparation of the bacterial suspension and phage $Q \beta$ suspension}

Escherichia coli JCM1649, Staphylococcus aureus FDA209P and phage $Q \beta$ were used for the disinfection and inactivation tests. E. coli, $S$. aureus and phage $Q \beta$ have been used as indicators of water pollution in the official examinations of disinfectants (Ohgaki et al.,1989). E. coli and S. aureus were incubated at $37^{\circ} \mathrm{C}$ with shaking for $20 \pm 2 \mathrm{~h}$ in a L-tube containing $10 \mathrm{ml}$ of the standard bouillon medium. The culture medium was transferred into a flask containing $150 \mathrm{ml}$ of the fresh bouillon medium, and incu- bated at $37^{\circ} \mathrm{C}$ for $18 \mathrm{~h}$ while being shaken. The cells of $E$. coli or $S$. aureus were collected by centrifugation and washed two times with $150 \mathrm{ml}$ of sterilized physiological saline, and suspended with $150 \mathrm{ml}$ of a sterilized distilled water. The number of bacterial cells in the suspension was adjusted to $10^{8}-10^{9} \mathrm{cfu} / \mathrm{ml}$ with the sterilized distilled water. This bacterial suspension $(0.15 \mathrm{ml})$ was re-suspended to $150 \mathrm{ml}$ with sterilized distilled water and adjusted to about $10^{6}$ cells $/ \mathrm{ml}$. The bacterial cell suspension was used for the disinfection test.

Phage $Q \beta$ was stocked at $4^{\circ} \mathrm{C}$ in a sterilized culture medium containing polypeptone $(10 \mathrm{~g})$, yeast extract $(5 \mathrm{~g}), \mathrm{MgSO}_{4}(0.2 \mathrm{~g}), \mathrm{MnSO}_{4}(0.005 \mathrm{~g})$, glucose $(1.5 \mathrm{~g})$ and $\mathrm{NaCl}(5 \mathrm{~g})$ dissolved in $1000 \mathrm{ml}$ of distilled water. The host strain, $E$. coli $\mathrm{K}_{12} \mathrm{~F}^{+} \mathrm{A} / \lambda$, was stocked on agar plates containing the phage $Q \beta$ cult ure medium at room temperature and sub-cultured every month. The phage $Q \beta$ stock culture medium $\left(0.1 \mathrm{ml}, 10^{9}-10^{10} \mathrm{pfu} / \mathrm{ml}\right)$ was suspended with $150 \mathrm{ml}$ of sterilized distilled water and the cell numbers were adjusted to $10^{6} \mathrm{pfu} / \mathrm{ml}$. The phage $Q \beta$ suspension was used for the disinfection test.

\section{Measurements of disinfection activity}

The disinfection test was carried out according to the shake-flask method (Hinokiyama, 1998). Cu-HT, $\mathrm{Zn}$-HT or HT500PF $(0.1-2.0 \mathrm{~g})$ was added to $150 \mathrm{ml}$ of the bacterial or phage $Q \beta$ suspension, and mixed by shaking. The $\mathrm{pH}$ value of each suspension was monitored continuously by a $\mathrm{pH}$ meter (TOA pH meter HM-30S). On $30 \mathrm{~min}, 0.1 \mathrm{ml}$ of the suspension was collected. The original bacterial and the phage $Q \beta$ suspensions were used as the control.

The disinfection effect was evaluated by examining the survival ratios of $E$. coli, $S$. aureus and phage $Q \beta$. The survival ratios of $E$. coli and $S$. aureus were calculated as follows. The suspension $(0.1 \mathrm{ml})$ was diluted to $10-10^{6}$ times with a $1 / 15 \mathrm{M}$ phosphate buffer solution $(\mathrm{pH} 7.0)$ and each diluted solution was put onto a nutrient agar plate. After incubation at $37^{\circ} \mathrm{C}$ for $24 \mathrm{~h}$, the viable cell number was counted. The survival ratio was calculated as the ratio between the viable cell numbers from the sample and these from the control.

TABLE 1. Chemical compositions of Cu-HT, Zn-HT and HT500PF.

\begin{tabular}{llcc}
\hline Hydrotalcite & \multicolumn{1}{c}{ Chemical composition } & $\begin{array}{c}\text { Concn of } \\
\text { copper or zinc surface area } \\
(\mathrm{mmol} / \mathrm{g})\end{array}$ & $\begin{array}{c}\text { Relative } \\
\left(\mathrm{m}^{2} / \mathrm{g}\right)\end{array}$ \\
\hline $\mathrm{Cu}-\mathrm{HT}$ & $\mathrm{Mg}_{0.806} \mathrm{Cu}_{0.09{ }_{4}} \mathrm{Al}_{0.194}(\mathrm{OH})_{2.07}\left(\mathrm{CO}_{3}\right)_{0.099}(\mathrm{Cl})_{0.115} \cdot 0.56 \mathrm{H}_{2} \mathrm{O}$ & 1.09 & 22.7 \\
$\mathrm{Zn}-\mathrm{HT}$ & $\mathrm{Mg}_{0.358} \mathrm{Zn}_{0.369} \mathrm{Al}_{0.269}(\mathrm{OH})_{1.94}\left(\mathrm{CO}_{3}\right)_{0.146}(\mathrm{Cl})_{0.033} \cdot 0.87 \mathrm{H}_{2} \mathrm{O}$ & 5.86 & 50.4 \\
HT500PF & $\mathrm{Mg}_{0.72{ }_{4} \mathrm{Al}_{0.258}(\mathrm{OH})_{1.94}\left(\mathrm{CO}_{3}\right)_{0.155}\left(\mathrm{SO}_{4}\right)_{0.002} \cdot 0.66 \mathrm{H}_{2} \mathrm{O}}$ & - & 35.0 \\
\hline
\end{tabular}


The survival ratio of phage $Q \beta$ was calculated as follows. The suspension $(0.1 \mathrm{ml})$ was diluted to $10-10^{2}$ times with a $1 / 15 \mathrm{M}$ phosphate buffer solution $(\mathrm{pH}$ 7.0). The number of viable phage $Q \beta$ cells in each of the diluted solution was counted by the plaque forming units method (Ohgaki et al.1991). The survival ratio of phage $Q \beta$ was calculated as the ratio between the number of plaques from the sample and that from the control.

The $\mathrm{pH}$ of the sterilized distilled water was adjusted to 9.5 by using $0.1 \mathrm{M}$ sodium hydroxide solution and $0.1 \mathrm{M}$ hydrochloric acid solution. The bacterial cell and phage $Q \beta$ suspensions were added to $150 \mathrm{ml}$ of the $\mathrm{pH} 9.5$ sterilized distilled water. The densities of bacterial cells and phage $Q \beta$ in suspension were adjusted to about $10^{6} \mathrm{cfu} / \mathrm{ml}$ and $10^{6} \mathrm{pfu} / \mathrm{ml}$, respectively. The survival ratio of the suspension at $\mathrm{pH} 9.5$ was measured by the disinfection test method described above.

\section{Measurements of amounts of hydroxide ions on the surfaces of $\mathrm{Cu}-\mathrm{HT}, \mathrm{Zn}-\mathrm{HT}$ and HT500PF}

The amounts of hydroxide ions on the surfaces of Cu-HT, Zn-HT and HT500PF particles were measured by the heat of adsorption of benzoic acid (Ueno et al., 1997). $10 \mathrm{mg}$ of Cu-HT, Zn-HT or HT50OPF suspension in $0.5 \mathrm{ml}$ of cyclohexane was added to a solution of $0.025 \mathrm{M}$ benzoic acid in cyclohexane. The heat of adsorption of benzoic acid on Cu-HT, Zn-HT and HT500PF was measured by using a Setaram micro differential scanning calorimeter (Setaram, MDSCIII). The amounts of hydroxide ions on each of the surfaces of Cu-HT, Zn-HT and HT500PF particles were calculated from both the heat of adsorption and the surface area of the particles.

\section{Measurements of amounts of copper or zinc eluted from Cu-HT and $\mathrm{Zn}-\mathrm{HT}$}

Each of $1 \mathrm{~g}$ of $\mathrm{Cu}-\mathrm{HT}$ or $\mathrm{Zn}$-HT was suspended with $150 \mathrm{ml}$ of sterilized distilled water, and the suspension was shaken under the stirring conditions. The $\mathrm{Cu}-\mathrm{HT}$ or $\mathrm{Zn}$-HT suspension was collected every $30 \mathrm{~min}$, and filtrated through a membrane filter (Millipore, cellulose nitrate, pore size $0.2 \mu \mathrm{m}$ ) for the removal of particles. Amounts of copper or zinc in these filtrates were measured by an inductively coupled plasma atomic emission spectrometer (Shimadzu ICP-2000).

\section{RESULTS AND DISCUSSION}

\section{Disinfection effect of Cu-HT, Zn-HT and HT500PF}

The survival ratios of $E$. coli, $S$. aureus and phage $Q$ $\beta$ treated with $0.1-2.0 \mathrm{~g}$ of $\mathrm{Cu}-\mathrm{HT}, \mathrm{Zn}-\mathrm{HT}$ and HT500PF for 120 min are shown in Fig. 1. As shown in Fig. 1 (a), no decrease in the survival ratios of $E$. coli, S. aureus and phage $Q \beta$ was found with the addition of $0.1-2.0 \mathrm{~g}$ of HT500PF. The results for $\mathrm{Cu}-$ $H T$ are shown in Fig. 1 (b). The survival ratios of $E$. coli and phage $Q \beta$ decreased according to the increase of the dosage. On the other hand, no decrease in the survival ratios of $S$. aureus was found by the increasing of the dosage. The survival ratios of $E$. coli and phage $Q \beta$ were decreased remarkably at dosage of $1.0 \mathrm{~g}$ and $2.0 \mathrm{~g}$. But no change in the survival ratio of $S$. aureus even at a dosage of $2.0 \mathrm{~g}$ was found. The results for $\mathrm{Zn}-\mathrm{HT}$ are shown in Fig. 1 (c). A slight decrease in the survival ratios of $E$. coli and phage $Q \beta$ was found at above a dosage of $0.5 \mathrm{~g}$. Similar results for $S$. aureus was found at a dosage of
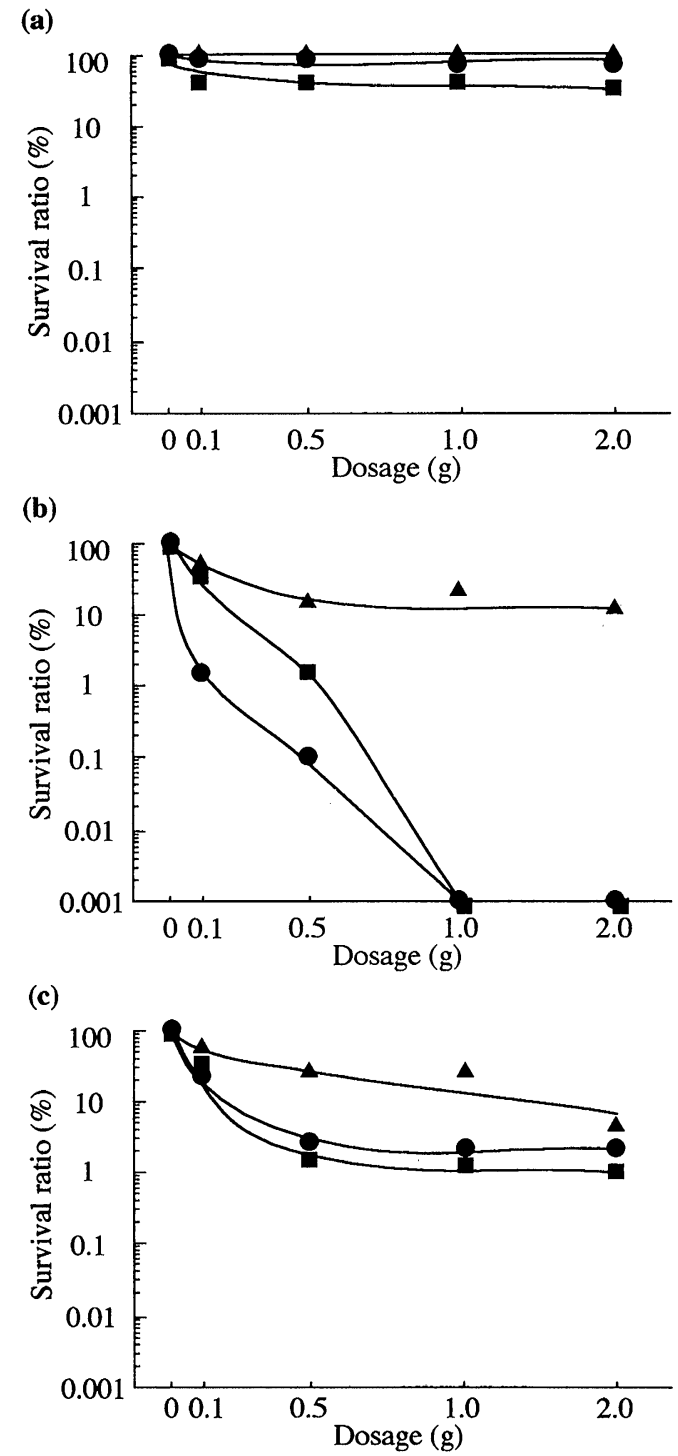

FIG. 1. Relationship between the survival ratios of $E$. coli

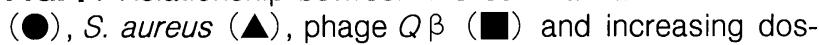
ages of HT50OPF (a), Cu-HT (b), Zn-HT (c) after stirring at 120min 
$2.0 \mathrm{~g}$.

From these results, it became clear that HT500PF containing hydrotalcites had no disinfection effect against $E$. coli, $S$. aureus and phage $Q \beta$. On the other hand, $\mathrm{Cu}-\mathrm{HT}$ containing hydrotalcites possessed a disinfection effect against $E$. coli and phage $Q \beta$. It was judged that $\mathrm{Zn}-\mathrm{HT}$ containing hydrotalcites possessed a slight disinfection effect against $E$. coli, $S$. aureus and phage $Q \beta$ at a dosage of $2.0 \mathrm{~g}$, but the disinfection effect of $\mathrm{Zn}-\mathrm{HT}$ was inferior to that of $\mathrm{Cu}$ HT.

A comparison of the disinfection activities of copper ion and zinc ion has been reported (Sato et al., 2000; Takayama., 1996). The disinfection activity of zinc ion against $E$. coli and $S$. aureus was inferior to that of copper ion. The MBC of copper ions against $E$. coli was about 2 times smaller than that against $S$. aureus. Then, it would appear that the disinfection activity of $\mathrm{Cu}-\mathrm{HT}$ was superior to that of $\mathrm{Zn}-\mathrm{HT}$. In this disinfection test, the amounts of copper and zinc at 1.0 $\mathrm{g}$ of $\mathrm{Cu}-\mathrm{HT}$ and $\mathrm{Zn}-\mathrm{HT}$ were $7.28 \mathrm{mM}$ and $39.1 \mathrm{mM}$, respectively. The amounts of zinc were 5 times larger than those of copper whereas the disinfection activity of $\mathrm{Zn}-\mathrm{HT}$ was inferior to that of Cu-HT. This results suggest that the disinfection activity of zinc was decreased significantly by adsorption in the hydrotalcite structure. In general, the disinfection effect of antimicrobial metal ions on the ionized type was higher than that on the de-ionized type (Hashimoto, 1996; Kaneko, 1973; Takayama, 1996). In the structure containing inorganic materials, the disinfection effect of metal was also affected by the charge condition. Metal in a condition of high charge was more effective than that in a condition of low charge (Danielli and Davis, 1951). The basic structure of the hydrotalcite compound produces the octahedral form of the divalent metal (Miyata, 1983; Sato and Shimada,1987), but the octahedral was changed to tetrahedral by the inserted zinc (Cavani et al., 1991). In comparing with the charge condition of zinc in the octahedral form with that in the tetrahedral, the charge condition of zinc in the later was lower than that in former (Kida, 1993). It was considered that the decrease in the disinfection effect of $\mathrm{Zn}-\mathrm{HT}$ would be based on the charge condition of zinc according to the change in the structure.

The disinfection effect of $\mathrm{Cu}-\mathrm{HT}$ and $\mathrm{Zn}-\mathrm{HT}$ was exemplified by the disinfection curves of $E$. coli, $S$. aureus and phage $Q \beta$ treated with $2.0 \mathrm{~g}$ of $\mathrm{Cu}-\mathrm{HT}$ and $\mathrm{Zn}$-HT. As shown in Fig. 2 (a), the disinfection curves of $E$. coli, $S$. aureus and phage $Q \beta$ with $\mathrm{Cu}-\mathrm{HT}$ were linear. The slope of $E$. coli was the biggest. The slope of phage $Q \beta$ was about 3 times smaller than that of $E$. coli. It was clear that the disinfection effect of Cu-HT against phage $Q \beta$ was inferior to that against $E$. coli. The slope of $S$. aureus was very small.

On the other hand, as shown in Fig. 2 (b), the disinfection curves of $E$. coli, $S$. aureus and phage $Q$ $\beta$ treated with $\mathrm{Zn}-\mathrm{HT}$ were linear, and the slopes were also very small.

The possibility of using Cu-HT and $\mathrm{Zn}-\mathrm{HT}$ as a disinfectant for the wastewater treatment system was evaluated according to the effluent standard of Japan. It is defined that the coliform number in wastewater was not more than $10^{3} \mathrm{cfu} / \mathrm{ml}$ in Japanese effluent standard treatment manual (Japan Sewage Works Association, 1992a). The standard method is treatment with $0.2-1.0 \mathrm{mg} / l$ of residual chlorine for more than 15 min (Kaneko,1998). The maximum numbers of coliform in the most polluted wastewater was about $10^{6}$ cells $/ \mathrm{ml}$. Therefore, in this experiment, the disinfection test was carried out by using $E$. coli cells in suspension $\left(10^{6} \mathrm{cfu} / \mathrm{ml}\right)$. For Cu-HT, according to the disinfection curve of $E$. coli treated with $2.0 \mathrm{~g}$, the survival numbers of $E$. coli went below $10^{3} \mathrm{cfu} / \mathrm{ml}$ after stirring time of $50 \mathrm{~min}$. From these results, it was considered that $\mathrm{Cu}-\mathrm{HT}$ could be used as a disinfectant for the wastewater treatment system if a sufficient stirring time.

On the other hand, the limit of virus numbers in
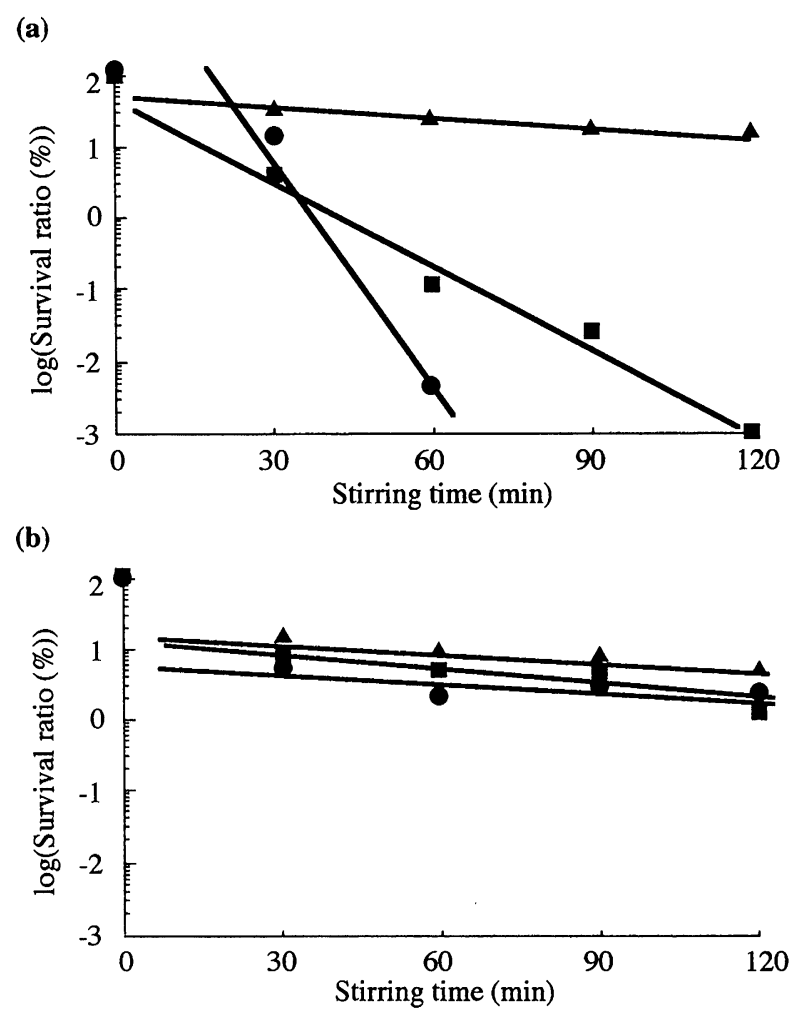

FIG. 2. The disinfection patterns of the survival ratios of $E$. coli $(\mathbf{O}), S$. aureus $(\boldsymbol{\Delta})$ and phage $Q \beta(\mathbf{\square})$ treated with $2.0 \mathrm{~g}$ of $\mathrm{Cu}-\mathrm{HT}$ (a) and $\mathrm{Zn}-\mathrm{HT}$ (b) 
wastewater has not determined yet in the effluent standard of Japan. However, there is some risk of viruses pollution the water in recent years. Cu-HT possesses the disinfection activity against phage $Q \beta$, and after a $120 \mathrm{~min}$ the number of plaque forming units (pfu) dropped from $10^{6} \mathrm{pfu} / \mathrm{ml}$ to $10^{1} \mathrm{pfu} / \mathrm{ml}$ with a dosage of $2.0 \mathrm{~g}$. It also seemed that the disinfection effect against phage $Q \beta$ was considerably strong. Also, the result would support the possible use of $\mathrm{Cu}$ $\mathrm{HT}$ as a disinfectant in the water treatment systems instead of chlorine. However, for $\mathrm{Zn}-\mathrm{HT}$ the stirring times at which the survival numbers of $E$. coli and phage $Q \beta$ decreased to $10^{3} \mathrm{cfu} / \mathrm{ml}$ and $10^{1} \mathrm{pfu} / \mathrm{ml}$ were $450 \mathrm{~min}$ and $1050 \mathrm{~min}$, respectively. From this result, it was judged that $\mathrm{Zn}$-HT could not be used as a disinfectant for wastewater treatment systems because of its weak disinfection activity.

\section{pH change in the hydrotalcites suspension}

Table 2 shows the $\mathrm{pH}$ change in the $\mathrm{Cu}-\mathrm{HT}, \mathrm{Zn}-\mathrm{HT}$ and HT500PF suspensions in the presence of $E$. coli. The original $E$. coli suspension was used as a control. The $\mathrm{pH}$ value of the suspensions with $\mathrm{Cu}-\mathrm{HT}$ and HT500PF after 120 min was 9.3 and 9.5, respectively, but that of $\mathrm{Zn}-\mathrm{HT}$ was 7.2. It was clear that the disinfection activity of $\mathrm{Zn}-\mathrm{HT}$ was not based on the change in $\mathrm{pH}$.

HT500PF possessed no disinfection activity. Cu-HT possessed remarkable disinfection activity (Fig. 1). It was clear that disinfection activity of $\mathrm{Cu}-\mathrm{HT}$ was not based on the change in $\mathrm{pH}$. The survival ratios of $E$. coli, $S$. aureus and phage $Q \beta$ at $\mathrm{pH} 9.5$ after $120 \mathrm{~min}$ were $93.2 \%, 94.3 \%$ and $49.5 \%$, respectively. The disinfection effect at $\mathrm{pH} 9.5$ was remarkably weak. From these results, it seemed to be confirmed that Cu-HT suspension possessed a remarkable disinfection activity that was not based on the change in $\mathrm{pH}$.

\section{Amounts of hydroxide ions on the surfaces of Cu-HT, Zn-HT and HT500PF}

The change in the $\mathrm{pH}$ in the $\mathrm{Cu}-\mathrm{HT}, \mathrm{Zn}-\mathrm{HT}$ and HT500PF suspensions caused by the dissociation of the hydroxide ion was based on the hydration of their surfaces. It is well known that the hydroxide ion layer formed on the surface of hydrotalcites possesses a similar structure to HT500PF (Sato et al.,1999). It was anticipated that hydroxide ion layer would be also formed on the surface of $\mathrm{Cu}-\mathrm{HT}$ particles. The disinfection effect of $\mathrm{Cu}-\mathrm{HT}$ was based on the formation of hydroxide ion. Because phage $Q \beta$ consists of only a shell of protein and nucleic acids, the shell of proteins would be easily denatured by alkalis.

Table 3 shows the amounts of hydroxide ions on the surfaces of Cu-HT, Zn-HT and HT500PF particles determined by the calorimetric heat method (Ueno et al.,1997). In this measurement, the heat of $1 \mathrm{~J}$ corresponds to $0.02 \mathrm{M}$ hydroxide ion. Zn-HT possessed the smallest amounts of hydroxide ions. On the other hand, Cu-HT had an amount 3 times larger than that of $\mathrm{Zn}-\mathrm{HT}$ and about 1.5 times larger than that of HT500PF. The survival ratios of E. coli, $S$. aureus and phage $Q \beta$ with $2.0 \mathrm{~g}$ of HT500PF were $85.1 \%$, $94.8 \%$ and $29.7 \%$, respectively. The decrease in the ratios of phage $Q \beta$ was small (Fig. $1 \mathrm{a}$ ). It was suggested that phage $Q \beta$ was inactivated by the hydroxide ion layer produced from the surfaces of HT500PF particles. Therefore, it is suggested that a hydroxide ion layer formed on the surfaces of $\mathrm{Cu}$-HT particles would contribute to the inactivation activity against phage $Q \beta$.

\section{The amounts of copper or zinc ion eluted from $\mathrm{Cu}-\mathrm{HT}$ and $\mathrm{Zn}-\mathrm{HT}$}

In the effluent standard of Japan, the concentrations of copper and zinc ions in wastewater are regulated below $3 \mathrm{mg} / l(47.2 \mu \mathrm{M})$ and $5 \mathrm{mg} / l$ (76.5 $\mu M$ ), respectively (Japan Sewage Works Association,1992b). Elution tests were carried out and the results are shown in Table 4. From the results, it was clear that the disinfection activity of $\mathrm{Cu}-\mathrm{HT}$ could mainly be attributed to copper in the structure. It was

TABLE 2. Time course of changes in $\mathrm{pH}$ with $2.0 \mathrm{~g}$ of $\mathrm{Cu}-\mathrm{HT}, \mathrm{Zn}-\mathrm{HT}$ or HT500PF suspension in the presence of $E$. coli.

\begin{tabular}{lccccc}
\hline \multirow{2}{*}{ Hydrotalcite } & \multicolumn{5}{c}{ Time (min) } \\
\cline { 2 - 6 } & 0 & 30 & 60 & 90 & 120 \\
\hline Cu-HT & $5.7^{a}$ & 9.2 & 9.3 & 9.3 & 9.3 \\
Zn-HT & 5.8 & 7.0 & 7.2 & 7.2 & 7.2 \\
HT500PF & 5.7 & 9.3 & 9.4 & 9.5 & 9.5 \\
None & 5.6 & 5.7 & 5.7 & 5.7 & 5.8 \\
\hline
\end{tabular}

${ }^{a} \mathrm{pH}$. 
TABLE 3. The amount of hydroxide ions on the surface of $\mathrm{Cu}-\mathrm{HT}, \mathrm{Zn}-\mathrm{HT}$, HT500PF.

\begin{tabular}{lccc}
\hline \multirow{2}{*}{ Item } & \multicolumn{3}{c}{ Hydrotalcite } \\
\cline { 2 - 4 } & $\mathrm{Cu}-\mathrm{HT}$ & $\mathrm{Zn}-\mathrm{HT}$ & HT500PF \\
\hline Enthalpy & $7.019^{\circ}$ & 4.800 & 6.309 \\
$(\mathrm{~J} / \mathrm{g})$ & & & \\
Hydroxide ion concn & 6.18 & 1.90 & 3.60 \\
(mmol/ $l$ ) & & & \\
\hline
\end{tabular}

${ }^{a}$ The heat of adsorption.

suggested that $\mathrm{Cu}-\mathrm{HT}$ could be used safely as a disinfectant. The increase in the amounts of zinc eluted from $\mathrm{Zn}$-HT was seen with the increase of the stirring time. It appeared that it would be difficult to use $\mathrm{Zn}-\mathrm{HT}$ as a disinfectant for the water treatment system.

The crystal structure of Cu-HT and $\mathrm{Zn}-\mathrm{HT}$ was analyzed by $\mathrm{X}$-ray powder diffraction before and after the experiment. Although, no change in the crystal structure of $\mathrm{Cu}-\mathrm{HT}$ was found, the crystal structure of $\mathrm{Zn}$ HT was partly destroyed after the experiment. When a zinc ion was introduced as a divalent metal, the crystal structure would change from the octahedral to tetrahedral form. From the elution of zinc from $\mathrm{Zn}-\mathrm{HT}$ in this experiment, it was considered that the change in the crystal structure from octahedral to tetrahedral would be closely related to the bactericidal activity.

It was clear that both the copper-containing hydrotalcite (Cu-HT) and zinc-containing hydrotalcite ( $\mathrm{Zn}-\mathrm{HT}$ ) possessed a disinfection activity. Especially, $\mathrm{Cu}$-HT possessed a remarkable disinfection activity against $E$. coli and phage $Q \beta$ and, moreover, no elution of copper ions was found from the particles. Therefore, the use of Cu-HT would be very safe from the epidemiological and environmental aspects, and we emphasize that a new disinfection system using $\mathrm{Cu}-\mathrm{HT}$ would be suitable for practical use in the water treatment field.
Cavani, F., Trifiro, F., and Vaccari, A. (1991) Hydrotalcitetype anionic clays: preparation, properties and applications. Catalysis Today, 11, 173-301.

Danielli, J. F., and Davis J. T. (1951) Reaction at interfaces in relation to biological problems. Adv. Enzymol., 11, 3589.

Japan Sewage Works Association (1992a) Sewage Testing Method (in Japanese). p.245-255, Japan Sewage Works Association.

Japan Sewage Works Association (1992b) Sewage Testing Method (in Japanese). p.187-194, Japan Sewage Works Association.

Hashimoto, K, and Toda, Y. (1996) Evaluation method of antimicrobial activity of ceramics materials with antimicrobaial characteristics and its application to phosphate compounds (in Japanese). Inorganic Materials, 3, 452459.

Hinokiyama, K (1998) Philosophy of efficiency estimation of antibacterial manufactured goods (in Japanese). Bokin Bobai, 26, 587-591.

Hirata, T., and Hashimoto, A. (1997) Abundance of cryptosporidium in water (in Japanese). Kankyou Gijyutsu, 26, 561-566.

Kaneko, M. (1997) Water Disinfection (in Japanese). pp.299-324, Environmental Improvement Education Center, Tokyo.

Kaneko, M. (1999) Domestic Wastewater Treatment System (in Japanese). pp.129-132, Gihoudou Shuppan, Tokyo.

Kaneko, M (1973) Toxic effects of metal to activated solid (in Japanese). Gesuidoukyoukai-shi, 10, 2-12.

Kawamoto, A., Ookubo, A., Sato, T., and Suzuki, T. (1999) Phosphorous removal from wastewater by layer structure

TABLE 4. Eluted amounts of metal from $1.0 \mathrm{~g}$ of $\mathrm{Cu}-\mathrm{HT}$ and $\mathrm{Zn}-\mathrm{HT}$ in $150 \mathrm{ml}$ of sterilized water.

\begin{tabular}{cccccc}
\hline \multirow{2}{*}{ Metal } & \multicolumn{5}{c}{ Time (min) } \\
\cline { 2 - 6 } & 0 & 30 & 60 & 90 & 120 \\
\hline Cu from Cu-HT & $0.0^{\circ}$ & ND $^{b}$ & ND & ND & ND \\
Zn from Zn-HT & 0.0 & 3.98 & 7.34 & 13.0 & 17.4 \\
\hline
\end{tabular}

${ }^{a}$ Amount of metal ( $\mu \mathrm{M}$ )

${ }^{b}$ Not detected. Detection limit was $0.16 \mu \mathrm{M}$. 
inorganic ion exchanger with high selectivity to phosphate anion (in Japanese). Mizu Kankyo Gakka-shi, 22, 875881.

Kida, S. (1973) Inorganic chemistry (in Japanese). Shokabo Shuppan, Tokyo.

Kourai, H. (1996) The present situation of inorganic antibacterial agent (in Japanese). J. Antibact. Antifung. Agents Jpn., 24, 509-515.

Miyata, S. (1983) Properties and adsorption characteristic of hydrotalcites (in Japanese). Gypsum Lime, 18, 333339.

Ohgaki, S., Ketratanakul, A., and Hashimoto, M. (1989) Indigeneous coliphages in small streams and sewage (in Japanese). Joukasou, 1, 19-24.

Ohkubo. A, Ooi K., Tani F., and Hayashi H. (1994) Phase transition of $\mathrm{Cl}^{-}$intercalated hydrotalcite-like compound during ion exchange with phosphates. Langmuir, 10, $407-$ 411.

Sato, T., and Shimada, M. (1987) Clay layer structure compound with anion exchange capacity (in Japanese). Science, 42, 64-65.

Sato, T., Sunayama, S., Suzuki, T., and Ookubo, A. (1998)
Improvement in water quality and disinfection of wastewater purifiers effluent by using inorganic ionexchangers and adsorbents as multifunctional water purifying materials (in Japanese). Joukasou, 10, 15-25.

Sato, T., Sunayama, S., and Suzuki, T. (2000) Disinfection effects of Antibacterial metal-holding hydroxyapatites against microbes in water (in Japanese). Bokin Bobai, 28, 237-245.

Sunayama, S., Sato, T., Suzuki, T., and Onodera, Y. (1999) Disinfection effects of silver ${ }^{-}$adsorbing allophane against microbes in water (in Japanese). Bokin Bobai, 27, 633640.

Taguchi, F., and Yano, K. (1988) The state of virus in water (in Japanese). J. Antibact. Antifung. Agents Jpn., 16, 233247.

Takayama M. (1996) The inorganic anti-fungus medicine and the action mechanism (in Japanese). J. Antibact. Antifung. Agents Jpn., 8, 561-567.

Ueno, S., Ebitani, K., Ookubo, A., and Kaneda, K. (1997) The active site in the heterogeneous Baeyer-Villiger oxidation of cyclopentanone by hydrotalcite catalysts. Appl. surface Sci., 121, 366-371. 